\title{
Geographies of Resistance
}

\section{Residential Schools, Colonial Policies, and Indigenous Resilience in Mid-Twentieth Century, British Columbia}

\author{
AUTHOR: Anastasia Kosteckyj \\ EDITED BY: Julia Richards, Julian Matheson, and Marisa Coulton
}

In historiography, residential schools are frequently constructed as one-dimensional spaces, and defined by their broader colonial agenda of assimilation. They were designed by the Canadian state to intervene in childhood, in an effort to isolate Indigenous children from their families, communities, and cultural identities. However, recent years have seen scholars challenge these oversimplified renderings of residential schools, and historians have attempted to define the more complex spatial and experiential geographies found within residential school spaces. ${ }^{1}$ Building off this discourse, this paper constructs residential schools as multi-dimensional sites of place and experience and demonstrates how these geographies simultaneously supported and opposed the Canadian colonial agenda. In this sense, residential schools can be understood as containing 'geographies of resistance,' wherein places of oppression can also be seen to include areas of resistance, resilience, and endurance.

To understand this view, one must consider the history of Canada's residential school system. Beginning in 1876, Indigenous children were placed at the centre of the Canadian colonial agenda. This paper examines government reports, statements from policymakers, and experiences of residential school students to demonstrate the state's persistent, and conscious focus on Indigenous children as targets for assimilation. These documents also reveal the racist and paternalistic attitudes that constructed residential schools. Ultimately, this paper contends that despite the principle design of residential schools to strip Indigenous children of their cultural identity, there were challenges by children to their teachings and their school institutions. This will be supported with specific examples obtained from the Truth and Reconciliation Commission (TRC), the Legacy of Hope Foundation, and oral testimonies.

Focusing more specifically on the experiences of children that attended residential schools in British Columbia (B.C.) during the midtwentieth century, this paper defines the intricate geographies of residential schools by referencing diverse acts of resistance by students. It further introduces geographical concepts, particularly, spatial and experiential geographies, to illustrate residential schools' material and experienced constructions. Consequently, this paper uses these conceptual understandings alongside historical evidence to argue that residential schools contained complex geographies of resistance. ${ }^{2}$

A review of Canada's history of colonial policies and their influence in the creation of the residential school systems assists in this multidimensional viewing. The implementation of Canada's residential school system was closely tied to the state's larger colonial project. In 1867 , Canada was a small Dominion of four provinces, and yet, its first leaders had large territorial aspirations. In particular, Canada's first Prime Minister, John A. MacDonald, had an expansionist vision for Canada and central to his domestic policy was westward expansion and settlement. In this planning, the 
Canadian state encountered what was referred to in discourse as the 'Indian Question.' That was, the question of what was to be done with Canada's Indigenous people as the Canadian nation-state grew and settler populations expanded onto lands traditionally held by Indigenous groups. ${ }^{3}$ Indigenous practices were seen to be incompatible with the state's vision for a Euro-western Canada. So, the late-nineteenth century Canadian Government responded to this question with a series of legislation, introduced piece-meal and aimed at the assimilation of Canada's Indigenous people. These were the blueprints that outlined how the state would 'civilize' the west of its 'savage' elements and integrate Indigenous populations into the AngloCanadian majority.

It was first suggested by Sir Robert Bagot in his 1844 Report on the Affairs of Indians in Canada, that the government should take steps to encapsulate the education of Indigenous children within their assimilation policy. ${ }^{4}$ It was argued by Bagot that in order to bring Indigenous people under the umbrella of Euro-western civilization, they needed to be instilled with the characteristics of civilization: knowledge and industry. ${ }^{5}$ In response to his recommendations, the Government of Canada included parameters in the Indian Act (1876) that mandated the state's authority to establish, operate and maintain schools for Indigenous children. ${ }^{6}$ Afterwards, John A. MacDonald tasked Nicholas Flood Davin, one of early Canada's political elites, with investigating and developing the education model that would best allow for the desired assimilation of Indigenous children. ${ }^{7}$

Davin recommended in his Report on Industrial Schools for Indians and Half Breeds (1879) that the state implement a system of denominational boarding schools. His report centred around his personal theory that the separation of Indigenous children from their parents and communities was necessary in order for the effective instillation of Euro-western teachings, and their continued practice past graduation. ${ }^{8}$ Davin believed that this system of education would best allow for the elimination of Indigenous identity, and that within a "generation or two," the results would be seen in Indigenous communities. ${ }^{9}$ This belief that the identities, cultures, and practices of an entire population could be purged and reengineered in a generation, was not only shared by Davin, but was also prevalent in political discourse and colonial thought. It was rooted in attitudes that constructed Euro-western cultures as superior to Indigenous cultures and these beliefs and values permeated into legislation.

Contained within the policies and legislation that sought administration over Indigenous people in Canada, were pervasive paternalistic and racist attitudes. In Davin's Report alone, he referred to Indigenous people as being a "subject race," that were "incapable of embracing the idea of a nation." 10 Davin described the "the Indian race" as being in its childhood, and thus unable to comprehend the "larger and nobler" future suggested for the young country. ${ }^{11}$ In response to this perceived problem, Davin reasoned that Indigenous children must necessarily be the subjects of Anglo-Canadian teachings for the state's desired assimilation to occur. He justified this by referencing the dominant sense of distrust and suspicion held by adult Indigenous people towards Euro-western society. $\mathrm{He}$ further asserted that Indigenous children were still impressionable and open to new teachings. ${ }^{12}$ Davin's views of Indigenous people were similarly echoed in other texts and statements made by senior Canadian policymakers in the latenineteenth century.

Compounding Davin's views was the 1847 Report on Industrial Schools, by Canadian political figure and education advocate Egerton Ryerson. He supported Davin's justifications for Indigenous schools when he suggested that Indigenous people would be best suited to training in agriculture and trades. This suggestion emerged from his belief that anything beyond a basic education for Indigenous people would be a waste of resources. ${ }^{13}$ Similarly, the Department of Indian Affairs in their 1890 Annual Report, suggested that 
it would be:

"highly desirable... to obtain entire possession of all Indian children after they attain to the age of seven or eight years, and keep them at schools of the industrial type until they have had a thorough course of instruction, not only in the ordinary subjects taught at public schools, but in some useful and profitable trade, or in agriculture, as the aptitude of the pupil might indicate he was best fitted for." 14

As Canadian historian-geographer Sarah de Leeuw observed in her 2007 article on residential school geographies, these collective sentiments mirrored the understanding in broader Canadian society that Indigenous people "would likely never surpass a place of the labouring or second class in Canada." 15 Persistent attitudes as to the racial and intellectual inferiority of Indigenous people prevailed in political discourse, and when combined with the moralist and paternalistic colonial sentiments already observed, they resulted in the construction of schools designed to educate Indigenous children in accordance with Euro-western values.

At least three things are evident in this history of residential schools. First, the young Canadian Government might be understood as asserting its sovereignty and nationhood through the residential school system. ${ }^{16}$ It is evident from political discourse that Canada's policy makers intended to expand their Dominion westward, and that Indigenous culture would have no place in the new state's order. This understanding is furthered by the colonial attitudes prevalent in late-nineteenth century residential school discourse. Indigenous people were expected to "disappear," primarily through assimilation to Euro-western expectations of them, in order to fulfill Canada's nationalistic goals. ${ }^{17}$

Second, it is evident that children were central to the state's plan for assimilation. This is particularly significant, since it demonstrates
Canada's specific focus on children as a means of acculturation. Due to the violent, abusive, and neglectful natures of most residential schools, this understanding is especially insidious. The above history of residential schools shows how EuroCanadian society viewed Indigenous people as racially inferior. These sentiments were also present in the pedagogy of residential schools. They led to practices that over time resulted in harmful, and even intergenerational impacts on students and their respective communities.

Some students that attended residential schools recalled feeling ashamed by their Indigenous heritage. Florence Horassi, in the 2015 Survivors Speak report from the TRC, remembered her time in residential school: "they told me I'm a dirty Indian, I'm a lousy Indian, I'm a starving Indian, and my mom and dad were drunkards, that I'm to pray for them." 18 Her recollection characterizes the shame that was ingrained in many children who went through the school system. Indigenous children were targeted physically, psychologically, and emotionally, and taught that their cultures, practices, and identities were not welcome in the Euro-western society's vision for Canada.

Third, the Canadian state designed residential schools for the purpose of assimilation. In his Report, Davin remarked that for schools to be successful in assimilating Indigenous children, the children had to be kept in a "circle of civilized conditions." ${ }^{19}$ Similarly, in her 2009 article on residential schools in British Columbia, de Leeuw observed discourse that remarked how residential schools should aim to "isolate the child as much as possible from his native background." 20 Thus, Indigenous children were forcibly removed from their homes, and relocated to isolated spaces designed to strip them of their very identities.

These understandings are important when considering the geographies of residential schools, and in particular, when constructing their spatial and experiential geographies. In her article, "Intimate Colonialisms: The Material and Experienced 
Places of British Columbia's Residential Schools," de Leeuw theorized the "nestedness" of residential schools. She argued that these sites can be interpreted both by "the subjects who occupy and make sense of it and by events and social interactions which also construct it." ${ }^{21}$ In particular, there are the material or spatial geographies (the physical locations of the space), and there are experiential geographies (how people engage with and interpret the space). Residential schools can thus be understood as much by the forces that created them, as they can by the experiences of those who engaged with them and in them. Building on de Leeuw's constructions of space, residential schools can come to be seen as complex spaces of interpretation.

De Leeuw's theoretical understandings can be used to help define residential schools as spaces of resistance. Similarly, in their 1997 work, Geographies of Resistance, Stephen Pile and Michael Keith outlined how resistance is the inevitable response to any social relation of power, and that resistance may not always be "glamorous or heroic," but "may subsist in enduring" in spaces of oppression. ${ }^{22}$ Central to Pile's spatialized construction of resistance is the "context in which acts of resistance take place - and significantly, the position of people within networks of power." ${ }^{23}$ In the context of residential schools, the everyday acts of children in defiance of institutional attempts to strip away their identities can certainly be considered important acts of resistance. The fact that such acts occurred in a space designed by hegemonic forces for their assimilation makes it even more significant. It is with this understanding that this paper shifts from the macro-level histories on the construction of Canada's residential school system and examines micro-level sites and experiences in residential schools that situate them as geographies of resistance.

By the 1920s, residential schools were well established across Canada, and it was the general consensus in political discourse that isolation was key to the state's assimilative goals. ${ }^{24}$ Hayter
Reed, as senior official of the Department of Indian Affairs, observed that residential schools were most effective when they were more remote, and their pupils collected from farther distances. ${ }^{25}$ This isolation, seen in both the material locations of the schools, and the experiential isolation of students separated from their families and communities, has been well documented by historians.

Survivors' statements, such as those contained in the 2015 Survivors Speak report from the TRC, also corroborate the lengths that were taken to construct the isolating geographies of residential schools. ${ }^{26}$ Former students of residential schools recalled the long journeys that they had to take from their home communities in order to attend their assigned schools. In one testimony, Howard Stacy Jones, remembered that he was kidnapped at age six from his elementary school in Port Renfrew and taken by Royal Canadian Mounted Police (RCMP) officers to the Kuper Island Residential School. ${ }^{27}$ This separation removed Jones from his home on Vancouver Island's west coast and transported him over a hundred kilometers to its east coast before he was ferried to a Gulf Island in what is now known as the Salish Sea. In a similar but separate account, Sphenia Jones, a Haida women, recalled her long journey from the Islands of Haida Gwaii to school in Edmonton - a distance of more than 1500 kilometers..$^{28}$ Children, sometimes as young as six, were taken on boats, buses, cattle trucks, trains, and planes; and transported occasionally even to different provinces for schooling. ${ }^{29}$ This history of residential schools, and the corroborating evidence from survivors help to construct their 'remote' characteristics. As material geographies, residential schools were isolated from Indigenous communities, and often, also from broader society. However, it is important to recognize that students also experienced the isolation of residential schools.

Building off of de Leeuw's constructions of residential schools as experiential geographies, the encounters and experiences of students help historians to define this complex understanding of residential school geographies. Not only were 
the material geographies of residential schools isolating, but so too were their policies and pedagogy. Students were not permitted to use their native languages; instead, they were forced to learn English and/orFrench. ${ }^{30}$ In her 2017 article, Historian Jane Griffith connected these policies to linguicide, the killing of language, and to the extinguishment of Indigenous language groups in Canada. ${ }^{31}$ Other historians have similarly referenced this practice as a form of cultural genocide.

In the Survivors Speak report, former students emotionally remembered when they were barred from speaking their own familiar languages. In B.C., Lily Bruce, a student at the Alberni Residential School, voiced her history of her first night at the school, and being told that she "wasn't allowed to speak Kwak'wala anymore." ${ }^{2}$ Bruce, who did not know English, could only "keep quiet" to avoid being punished. ${ }^{33}$ Her story, and the stories of others told in survivor histories add an additional layer to understanding how residential schools were isolating places. Students had the central structures in their lives - speech and language denied to them. This is an isolation of a different kind, not a physical separation, but a psychological and emotional 'othering,' as Indigenous children were targeted on the basis of their cultural and identities.

Residential schools were sites of oppression, and their histories are laden with widespread harms, abuse, and neglect. The design of residential schools, their forms of discipline, and their educational policies were all manufactured to inscribe Euro-western values onto the bodies, minds, and lives of Indigenous children. John Milloy, in his extensive history on the subject, succinctly summarized how the stripping of Indigenous identity from students was an inherently violent process and how in residential schools "discipline was curriculum and punishment was pedagogy." 34 Yet, in spite of these circumstances, there are instances when children, through their actions and experiences found small ways to mount resistance. In doing so, they also demonstrated how it was possible to work 'in between' the spaces of authority and resist. Contained within relatively small school-spaces, and the micro-histories of residential schools, are geographies of resistance.

A complete study on the histories of resistance in Canadian residential schools requires considerably more attention and resources than can be offered in a short examination such as this. Some historians, such as Celia Haig-Brown, have begun to examine this distinct faction of Indigenous history. ${ }^{35}$ Nonetheless, the different types of resistance, and the understanding that Indigenous children engaged in resistance at their schools, is central to constructing the complex geographies of these sites. Through small acts, such as those remembered by some of the students that attended school in B.C. during the mid-twentieth century, residential schools became sites of resistance, where children challenged and fought against the hegemonic forces that attempted to change them.

One of the ways that Indigenous children would resist their residential schools was simply by leaving them. Education for Indigenous children was not voluntary. It was enforced through state mechanisms, like through the RCMP and local Indian Agents. As a result, attempts by students to leave the schools can be seen as children's resistance against the state, their policies of enforced education, and significantly, the conditions in the residential schools. In oral histories, such as some of those documented in the Legacy of Hope Foundations' online archives, Where Are the Children, survivors of residential schools shared some of these stories.

Lucille Mattess, from the Tl'azt'en Nation, attended the Lejac Indian Residential School in Fraser Lake during the 1960s. She recounted her various attempts to run away from the school, the punishments she endured, and her persistent resistance to her forced attendance. ${ }^{36}$ When Mattess was returned to the school (for the third or fourth time), she remembered telling the staff: "I told them that I'm never ever going to run away 
from Lejac again. I'm going to demand that I be released from this prison... we disrupted the whole school for two months, we disrupted the whole school demanding to go home." 37 Mattess also testified that she was finally permitted to go home that year, after her complaints, and the complaints of her fellow students, were finally heeded by the Priests. ${ }^{38}$

In a separate account, Ivan George recalled how he and a group of friends ran away from their residential school in Mission, B.C. and made it to Abbotsford before someone picked them up and returned them to their school. ${ }^{39}$ After being given a warning, and told: "[n]ext time you get the strap," George made another attempt a month or so later but was picked up by police and returned again. ${ }^{40}$ He notes in his testimony to the TRC that two months after these events, "me and this other guy decided to run again" making it home to Chilliwack before the Indian Affairs official sent them back. ${ }^{41}$

The context of Mattess' and George's stories, and stories like theirs, are important in considering how residential schools can be seen as geographies of resistance. A seemingly small act, running away can be seen as a response to the oppressive conditions that surrounded children in residential schools. It is also significant due to the overwhelming state power held over Indigenous children (and Indigenous communities in general) at this time in history. In spite of all their efforts, and in spite of their strict punishments for disobedience, residential schools failed to contain Indigenous children. Furthermore, the fact that these experiences occurred, and endure in history, demonstrates how important it is to consider residential schools as multi-dimensional sites of experience. Not only were they places that children were sent to, but they were also places where some students refused to be, and fought in the face of harsh discipline to leave. It is also worth mentioning that a number of students risked their lives and safety in running away, and they did so in order to escape the oppressive, abusive conditions they faced in their residential schools. These instances are acknowledged and recorded in the 2016 Report from the TRC; Canada's Residential Schools: Missing Children and Unmarked Burials.

Students also engaged in symbolic methods of resistance, such as refusing to show weakness in the face of the schools' harsh methods of punishment or discipline. In the Survivors Speak report, Tina Duguay, recalled receiving one hundred strokes of the strap on each hand at her residential school in B.C. ${ }^{42}$ Tina remembered telling herself: "This time they're not breaking me. I don't care what, they're not gonna break me," and waiting until the nun had left before showing her emotional distress to her friend. ${ }^{43}$ Another student, identified in Celia Haig-Brown's history of residential schools by the pseudonym 'Sophie,' testified to similar experience at the Kamloops Indian Residential School during the 1930s:

"I knew I was going to get five or ten straps on each hand and I knew it was going to draw blood-but I would remind myself, 'It's not going to hurt. Just so I can make [the nun] angry, I'm not going to let [her] know it hurts...' and I would just stare at her in the face... and I wouldn't even let a drop, a tear come down. God, that used to make her mad. She'd even take me and shake my head and say, 'The devil is in you so strong. How am I going to beat the devil out of you?' She'd put me in a dark place and tell me to stay there. I was a bad example for the rest." 44

These demonstrations of strength can be seen as a type of endurance to the oppressive conditions and punishments in the residential schools. Sophie later said of her experience at the Kamloops school, that in spite everything she endured, in particular the emotional distress, she was able to gain strength from what she went through. ${ }^{45}$

Another important form of resistance to residential schools were the efforts made by students to maintain their cultural connections, 
predominantly through the preservation of their languages. Residential schools were set up with the express purpose of assimilating Indigenous children into Euro-western Canadian society. As a result, Indigenous languages were prohibited in residential schools and students were often punished for using them. However, students found spaces within their schools where they were able to practice these basic forms of expression and culture. In her work, Haig-Brown noted the story of 'Mary,' a Shuswap student at the Kamloops Indian Residential School from 1940-1951. Mary remembered how during her first year at the school, an older student counseled her about the places and ways in which she could use her language: "[w] hen we were way out there, we'd talk together in our language." 46

In a similar account, Haig-Brown noted how 'Nancy,' a Chilcotin speaker, "held defiantly to her language" while attending the Kamloops Residential School. ${ }^{47}$ Nancy recalled: "I was trying to remember one word and that was squirrel and it was so easy... I remember struggling with it all day and trying to remember. And then at night when I went to bed, I kept thinking about it and I thought and thought and then it came up." ${ }^{48}$ The isolating and acculturating designs of residential schools attempted to strip Indigenous students of their language and culture. By practicing, enduring, and refusing to forget, students engaged in acts of resistance in spaces created to oppress their Indigeneity.

Other acts of resistance, chronicled by scholars, are the ways in which children rebelled against their gendered educations, and segregation from the opposite sex. Haig-Brown noted that girls in B.C. residential schools would sometimes experiment with makeup and hairstyles, in spite of the focused religious education on modesty. ${ }^{49}$ Additionally, communication between girls and boys occurred in the schools despite its illicitness, and the strict efforts at gender-based segregation. ${ }^{50}$ Although some may find these minor acts of rebellion insignificant, the context and place in which they occurred gives meaning and depth to these experiences. Indeed, the subject of resistance in the history of residential schools certainly merits further investigation.

In sum, this paper has provided a brief history of the policies that established and constructed residential schools in the late-nineteenth century. Contained within many colonial macro-histories are attempts by the hegemonic forces to assimilate and erase Indigenous cultures from the Canadian landscape. Similarly, in the histories on residential schools, there are blatant racial and paternalistic sentiments in teaching and pedagogy. However, these are not the only histories of these sites. It is important to understand the lengths students went through to mount resistance and the significance of these actions.

By employing concepts found in geography - material, experiential, and geographies of resistance - one can begin to construct a new conceptual viewing of the complex, multidimensional natures of residential schools and their histories. This form of examination builds on the work of scholars like Sarah de Leeuw, and challenges the traditional understandings of residential schools as being entirely static, oppressive and acculturating. Although this paper has shown how these were principle features in the colonial design for residential schools, examining accounts from students helps to construct a more complex viewing of these sites. Similarly, reading against the grain to view students' acts of defiance and endurance as forms of resistance further complicates traditional narratives and provides possible avenues for future research. Despite the focus of this paper on schools in B.C. during the mid-twentieth century, it is possible that this topic could be explored more broadly and expanded to include other geographies.

In recent years there have been various movements to voice the injustices suffered by Indigenous children at residential schools. Some have grassroots and are organized by the survivors 
of these places; others are reactionary and come from the political realm. However, by engaging with survivors of residential schools, individuals are able to express the varied and diverse narratives in these histories. It is important, going forward, for historians to incorporate these voices into their examinations, as they provide renewed perspectives from which to examine the past.

Residential schools should not be considered one-dimensional spaces. Their experiential geographies, as told through the histories of students who attended them, give these sites body and depth. Residential schools were not only places of oppression, but also spaces of resistance, where children opposed the forces that attempted to strip them of their identities. It should be acknowledged that the students that attended residential schools were not only victims, but also fighters against institutional injustices and state oppression. Residential schools in Canada are a topic of particular sensitivity. However, it is important to recognize the various ways in which people engaged with these sites, and to recognize that in the face of state-enforced oppression, small actions and small bodies were able to demonstrate strength, endurance, and resistance.

\section{ENDNOTES:}

1. This paper adopts a human geographer's understanding of "geography": defined as understandings regarding the study of places and individuals interactions with those places. In this context, "geography" and its plural "geographies" are used in reference to the nature, arrangement, features, and experiences within residential schools. Residential schools contained physical/ spatial geographies related to their isolated constructions and physical features. They also contained experiential/imagined geographies constructed by those who interacted with each place. See: Sarah Sarah de Leeuw, "Intimate Colonialisms: The Material and Experienced Places of British Columbia's Residential Schools," The Canadian Geographer 51, no. 3 (2007): 339359.
2. Implicit in the term 'geographies of resistance' is an understanding that spaces and places can be socially constructed and linked to social relations of power. Steve Pile and Michael Keith note that in spaces of oppression, there are acts of resistance to repressive, harmful, and contemptible means of enforced, and typically hegemonic power. These forms of resistance can vary from transgression, to opposition, to simply endurance. See:

Steve Pile and Michael Keith, Geographies of Resistance, (London: Routledge, 1997).

3. Dominion of Canada, Department of Indian Affairs, Annual Report of the Department of Indian Affairs for the Year Ended December 31, 1890, (Ottawa: ON: Brown Chamberlain), 1. http://central.bac-lac.gc.ca/.item/?id=1890-IAARRAAI\&op=pdf\&app=indianaffairs.

4. Sarah de Leeuw, "If anything is to be done with the Indian, we must catch him very young': Colonial Constructions of Aboriginal Children and the Geographies of Indian Residential Schooling in British Columbia, Canada," Children's

Geographies 7, no. 2 (2009): 126-7.

5. Milloy, A National Crime, 13.

6. Dominion of Canada, House of Commons, Indian Act, (Ottawa, ON: House of Commons, 1876), http://nctr.ca/assets/reports/Historical\%20 Reports/1876\%20Indian\%20Act.pdf.

7. De Leeuw, "If anything is to be done with the Indian, we must catch him very young,"' 129. 8. Nicholas Flood Davin, Report on Industrial Schools for Indians and Half Breeds, (Ottawa, ON: Report to the Minister of the Interior, 1879): 12, https://ia601402.us.archive.org/22/items/ cihm_03651/cihm_03651.pdf.

9. Davin, Report on Industrial Schools for Indians and Half Breeds, 10.

10. Ibid., 10-11.

11. Ibid., 11.

12. Ibid.

13. A. Egerton Ryerson, Education Office, Report on Industrial Schools, (Ottawa, ON: Education Office, 1847), 73. http://nctr.ca/assets/reports/ Historical\%20Reports/Ryerson\%20Report.pdf. 14. Dominion of Canada, Department of Indian Affairs, Annual Report of the Department of 
Indian Affairs for the Year Ended December 31, 1890, (Ottawa: ON: Brown Chamberlain), 1. http://central.bac-lac.gc.ca/.item/?id=1890-IAARRAAI\&op=pdf\&app=indianaffairs .

15. Sarah de Leeuw, "Intimate Colonialisms: The Material and Experienced Places of British Columbia's Residential Schools," The Canadian Geographer 51, no. 3 (2007): 342.

16. Milloy, A National Crime, 126

17. Davin, Report on Industrial Schools for Indians and Half Breeds, 11.

18. Florence Horassi, as quoted in: Canada, Truth and Reconciliation Commission, The Survivors

Speak, (Ottawa: ON, Library and Archives Canada), 104. http://nctr.ca/assets/reports/ Final\%20Reports/Survivors_Speak_English_Web. pdf.

19. Davin, Report on Industrial Schools for Indians and Half Breeds, 12.

20.De Leeuw, "If anything is to be done with the Indian, we must catch him very young,"' 131.

21. De Leeuw, "Intimate Colonialisms," 343.

22. Pile and Keith, Geographies of Resistance, i.

23. Steve Pile, "Opposition, Political identities, and Spaces of resistance," in Geographies of Resistance, ed. Steve Pile and Michael Keith (London: Routledge, 1997), 15.

24. Milloy, A National Crime, 28.

25. Hayter Reed as cited in: Milloy, National Crime, 30.

26. See: Canada, Truth and Reconciliation Commission, The Survivors Speak, (Ottawa: ON, Library and Archives Canada), 13-19, 23-31.

27. Howard Stacy Jones as quoted in Canada, Truth and Reconciliation Commission, The Survivors Speak, (Ottawa: ON, Library and Archives Canada), 23.

28. Sphenia Jonas as quoted in Canada, Truth and Reconciliation Commission, The Survivors Speak, (Ottawa: ON, Library and Archives Canada), 27-28.

29. Canada, Truth and Reconciliation Commission, The Survivors Speak, (Ottawa: ON, Library and Archives Canada), 23-31.

30. De Leeuw, "Intimate Colonialisms," 342.

31. Jane Griffith, "Of Linguicide and Resistance:
Children and English Instruction in NineteenthCentury Indian Boarding Schools in Canada," International Journal of the History of Educaiton 53, no. 6 (2017): 765.

32. Lily Bruce as quoted in Canada, Truth and Reconciliation Commission, The Survivors Speak, (Ottawa: ON, Library and Archives Canada), 48. 33. Ibid.

34. Milloy, A National Crime, 42.

35. See: Celia Haig-Brown, Resistance and Renewal: Surviving the Indian Residential School, (Vancouver: Arsenal Pulp Press, 1988).

36. Lucille Mattess, interview by Where Are the Children, "Lejac Indian Residential School," transcript, Legacy of Hope Foundation. http:// wherearethechildren.ca/en/stories/\#story_1/

37. Mattess, interview by Where Are the Children, "Lejac Indian Residential School."

38. Ibid.

39. Ivan George as quoted in Canada, Truth and Reconciliation Commission, The Survivors Speak, (Ottawa: ON, Library and Archives Canada), 134. 40. George as quoted in Canada, The Survivors Speak, 134.

41. Ibid.

42. Tina Duguay as quoted in Canada, Truth and Reconciliation Commission, The Survivors Speak, (Ottawa: ON, Library and Archives Canada), 148. 43. Ibid.

44. 'Sophie' as quoted in Haig-Brown, Resistance and Renewal, 103.

45. Ibid., 116.

46. 'Mary' as quoted in Haig-Brown, Resistance and Renewal, 104.

47. Haig-Brown, Resistance and Renewal, 104. 48. 'Nancy' as quoted in Haig-Brown, Resistance and Renewal, 104.

49. Haig-Brown, Resistance and Renewal, 98101.

50. Ibid., 98.

\section{BIBLIOGRAPHY:}

Canada. Truth and Reconciliation Commission. Canada's Residential Schools: The History, Part 1 Origins to 1939. Ottawa: ON, Library and Archives Canada. http://nctr.ca/assets/ 
reports/Final\%20Reports/Volume_1_ History_Part_1_English_Web.pdf.

Canada. Truth and Reconciliation Commission. The Survivors Speak. Ottawa: ON, Library and Archives Canada. http://nctr.ca/assets/ reports/Final\%20Reports/Survivors_Speak_ English_Web.pdf.

Dominion of Canada. House of Commons. Indian Act. Ottawa, ON: House of Commons, 1876. http://nctr.ca/assets/reports/Historical\%20 Reports/1876\%20Indian\%20Act.pdf.

Davin, Nicholas Flood. Report on Industrial Schools for Indians and Half Breeds. Ottawa, ON: Report to the Minister of the Interior, 1879. https://ia601402.us.archive. org/22/items/cihm_03651/cihm_03651.pdf.

De Leeuw, Sarah. "If anything is to be done with the Indian, we must catch him very young': colonial constructions of Aboriginal children and the geographies of Indian residential schooling in British Columbia, Canada." Children's Geographies 7, no. 2 (2009): 123140. DOI: $10.1080 / 14733280902798837$.

De Leeuw, Sarah. "Intimate Colonialisms: The Material and Experienced Places of British Columbia's Residential Schools." The Canadian Geographer 51, no. 3 (2007): 339359.

Dominion of Canada. Department of Indian Affairs. Annual Report of the Department of Indian Affairs for the Year Ended December 31, 1890. Ottawa: ON: Brown Chamberlain. http://central.bac-lac.gc.ca/.item/?id=1890IAAR-RAAI\&op=pdf\&app=indianaffairs.

Griffith, Jane. "Of Linguicide and Resistance: Children and English Instruction in Nineteenth-Century Indian Boarding Schools in Canada." International Journal of the
History of Education 53, no. 6 (2017): 763782. DOI: $10.1080 / 00309230.2017 .1293700$.

Haig-Brown, Celia. Resistance and Renewal: Surviving the Indian Residential School, (Vancouver: Arsenal Pulp Press, 1988).

Mattess, Lucille. Interview by Where Are the Children. "Lejac Indian Residential School." Transcript, Legacy of Hope Foundation. http://wherearethechildren.ca/en/ stories/\#story_1/.

Milloy, John S. A National Crime: The Canadian Government and the Residential School System, 1879 to 1986. Manitoba: University of Manitoba Press, 1999.

Pile, Steve. "Opposition, Political Identities, and Spaces of Resistance." In Geographies of Resistance, edited by Steve Pile and Michael Keith, 1-32. London: Routledge, 1997.

Pile, Steve and Michael Keith. Geographies of Resistance. London: Routledge, 1997.

Ryerson, A. Egerton. Education Office. Report on Industrial Schools. Ottawa, ON: Education Office, 1847. http://nctr.ca/assets/reports/ Historical\%20Reports/Ryerson\%20Report. pdf 